\title{
8. Migration from China to the EU: The Challenge within Europe
}

\author{
Bin Wu and Kevin Latham
}

\begin{abstract}
At the beginning of the 21st Century, we have witnessed a rapid growth in Chinese immigration to the European Union (EU), which has had a profound impact on local Chinese communities in various ways. This chapter aims to reveal the latest developments in Chinese immigration in the EU, as well as the new dynamics, features and impacts on local Chinese communities. The above questions are addressed by a combination of secondary data analysis and our own observation in Italy and the UK in recent years. Some challenging issues facing Chinese communities are highlighted.
\end{abstract}

\section{Introduction}

As a part of China's rise and "going global" strategy since the late 1990s, more and more Chinese citizens have joined the flow of international migration (Wang and Liu, 2011). The unprecedented process of Chinese international migration has had a profound impact on major destinations in various ways.

With regard to Europe, the literature on Chinese immigration can be roughly divided into three areas: works dealing with the international movement and working conditions of low-or un-skilled Chinese immigrants (Pieke at al 2004; Gao, 2010; Pai, 2009; Zanin and Wu, 2012; Wu and Liu, 2013); those looking at Chinese international student migration and circulation (Shen, 2009) and those considering the history and latest developments of Chinese Diasporic communities (Benton and Pieke, 1998; Chan, 2005; Benton and Gomez, 2008;). It is commonly recognised, furthermore, that overseas Chinese communities in Europe and beyond are diverse, segmented and fragmented, which prevent them integrating into the mainstream society (Wang and Liu, 2011; Wu and Sheehan 2012; Liu, 2013). With respect to the on-going transformation within local Chinese communities in Europe, it is important to ask: how has the new wave of Chinese immigration influenced Chinese communities in Europe and what are the new challenges for the community development and integration? The above questions will be addressed through an analysis of official information', plus our own observations in Veneto and Prato, Italy (Zanin and Wu, 2012; Latham 2010) and the East Midlands, UK (Wu, et al 2010). This chapter attempts to shed new light on the links between the latest developments in Chinese international immigration, changes in local Chinese communities in destination countries and their processes of integration.

\section{Chinese immigration and its impact on the growth of the Chinese Diaspora in the EU}

China's economic reform and open door policies starting from the late 1970s have resulted in not only large scale capital and commodity flows across its borders but also increasing mobility of its citizens both internally and internationally (Benton and Pieke 1998; Li and Roulleau-Berger 2012; Yeung 2002). In relation to the new wave of Chinese international migration, furthermore, we have witnessed rapid growth in the overseas Chinese population world-wide. According to an estimate by Gui (2011:54-55), the total overseas Chinese population world-wide has increased from 27 million in 
1983 to 40 million in 2000 and 45 million in 2007. Despite a small share (less than 5 per cent) of the world total, Europe has experienced a rapid growth in the Chinese population from 0.60 million in 1980 to 1.45 million in 2000 and jumping to 2.15 million in 2007 (see Table 1). With a focus on the period from 2000 to 2007, in particular, the growth rate in Europe was about 48.3\%, considerably higher than the $12.5 \%$ global growth rate over the same period. The impact of the new wave of Chinese immigrants varies greatly with region. Compared with other regions, Europe is more sensitive with regard to the new wave of Chinese immigrants due to the relatively small size of the Chinese population in the past and its low profile in public perception (Wang and Liu 2011: ).

With a focus on EU, the impact of the new wave of Chinese immigration in local Chinese communities varies greatly from country to country (see Table 1$)^{1}$. Some 87 per cent are concentrated in the top 6 countries by size of Chinese population: the UK, France, Italy, Spain, Germany, and Netherlands. This is due partly to the colonial history of the UK and France and to the work, benefits and commercial opportunities available in those four states. Italy and Spain have implemented amnesties for illegal immigrants over the past couple of decades, and Italy has been a convenient place for Chinese to conduct business, particularly in the grey and black markets.

Table 1: Growth and distribution of the Chinese population in the EU, 1998-2008

\begin{tabular}{|c|l|rr|c|}
\hline Rank & \multicolumn{1}{|c|}{ Country } & \multicolumn{1}{c}{1998} & 2008 & $2008 / 1998$ \\
\hline 1 & United Kingdom & 250,000 & 600,000 & 2.40 \\
2 & France & 225,000 & 500,000 & 2.22 \\
3 & Italy & 70,000 & 300,000 & 4.29 \\
4 & Spain & 35,000 & 168,000 & 4.80 \\
5 & Germany & 100,000 & 160,000 & 1.60 \\
6 & Netherlands & 127,500 & 150,000 & 1.18 \\
7 & Ireland & 10,000 & 60,000 & 6.0 \\
8 & Belgium & 23,000 & 40,000 & 1.74 \\
9 & Austria & 20,000 & 40,000 & 2.0 \\
10 & Portugal & 2,700 & 30,000 & 11.1 \\
11 & Sweden & 12,800 & 30,000 & 2.34 \\
12 & Denmark & 12,800 & 18,000 & 1.41 \\
13 & Greece & 600 & 12,000 & 20.0 \\
14 & Hungary & 10,000 & 16,000 & 1.60 \\
15 & Romania & 3,000 & 10,000 & 3.33 \\
& Other & 16,320 & 19,970 & 0.54 \\
& EU Total & 939,720 & $2,153,970$ & 2.29 \\
\hline
\end{tabular}

Sources:2008 data are based upon an estimate by the European Chinese Association. The 1998 data are from Minghuan Li, 'Analysis of Chinese population in Contemporary Europe'. Both sets are quoted in Qu et al., 2011: 23, 57.

Table 1 also highlights (in italics) those countries which have experienced fast growth in the Chinese population over the last decade. ${ }^{3}$ The majority of these countries are more peripheral countries of Europe (Italy, Spain, Portugal, Greece and Ireland), with their own histories of emigration in the past.

\footnotetext{
${ }^{1}$ In this table, 'Chinese' refers broadly to people of Chinese ethnic origin, including older generations of Chinese immigrants from Hong Kong and Indochina.

${ }^{2}$ It is important to note that due to the variety of sources and methods of data collection, a certain caution is necessary when considering official statistics across the EU in terms of accuracy and consistency. For instance, irregular migrants are not included in official statistics, which leads to an underestimate of the true Chinese population.
} 
A number of observations can be drawn from Table 1. Firstly, the new cohort of Chinese immigrants has, to varying degrees, made a significant contribution to an expansion of local Chinese communities in almost all EU member countries since the late 1990s. Secondly, we have witnessed accelerating growth of Chinese populations not only in the new destination countries in southern Europe but also in those old destinations in western and northern Europe such as the UK, France and Germany.

\section{Factors behind the new wave of Chinese immigration}

Having identified the new wave of Chinese immigrants and its contribution to the growth of local Chinese communities in host countries in the last decade or so, this section attempts to identify some of the principal factors which have played a significant role in fostering this process. In particular, we concern ourselves with state-owned enterprise (SOE) reform, China-Europe trade, rising consumer power and inequalities in China, as well as the internationalisation of higher education.

State-owned enterprise (SOE) reform. In the late 1990s, SOE reform led to the closure or transfer of hundreds of thousands of small and medium-sized SOEs into private hands or joint venture administration with tens of millions of SOE employees being made redundant (CLIN, 1999). The effects of SOE reform varied greatly from region to region: Northeast China (or Dongbei in Chinese), the country's heavy industrial heartland and home to many SOE workers, was one of the most seriously affected regions. The vast majority of redundant workers were forced to migrate to other regions of China or to seek employment in the service sector, but a large number of former SOE employees also went abroad, mainly to Europe, in search of alternative business and job opportunities (Blanchard and Maffeo, 2011: 74-75). This has reshaped Chinese immigrant communities in Europe in terms of both local Chinese labour supply, and the geographical location of sending communities in mainland China. As a result, the proportion of Europe's Dongbei Chinese immigrant population has been growing rapidly, making people from that region a more prominent and influential group in some Chinese communities alongside those new immigrants from south China (mainly from Zheijiang and Fujian provinces). ${ }^{4}$

China-Europe trade. China's rise in the international community has seen an increasing interconnection and interdependence between China and Europe in all fields. This includes international trade and mutual investment, which has provided a sound base and strong demand for international migration. From 1999 to 2009 for instance, international trade between China and Europe increased from US\$68.1 billion to US\$427 billion, slightly faster than the average total growth rate of China's total international trade. Foreign direct investment (FDI) from Europe to China has remained fairly constant, increasing by only 15 percent over this period even though the total scale of FDI has doubled. By contrast, there has been a rapid growth of outward direct investment (ODI) from China to Europe, from just US\$500million in 2005 to over US\$3 billion in 2009, an increase of 6.6 times in just four years. The rapid development of China-Europe economic collaboration in the past decade has had a profound impact on Chinese international migration to Europe in several ways. These include the diversification of Chinese business interests away from the

\footnotetext{
${ }^{3}$ That is growth of more than 2.3 times the mean growth rate of the Chinese population in the EU in the period from 1998 to 2008,

${ }^{4}$ This is witnessed by some European Chinese newspapers which offer increasing numbers of news stories on the north-east of China. The Italian published Europe China News (欧洲侨报) for instance now regularly has a page for Dongbei and Fujian news in addition to its Wenzhou and Lishui section, the largest proportion of Overseas Chinese in much of Europe coming from the Wenzhou and Lishui areas of Zhejiang province.
} 
traditional catering sector to other areas of commerce, manufacturing and personal services (Pastore and Castagnone, 2011: 9; Cologna 2011) ranging from the sale of everyday items and hardware to traditional Chinese medicine and services, such as accommodation and catering, for the increasing number of Chinese tourists and business delegations coming to Europe (Arlt 2011). It has also led to increasing demand for Chinese international migration in order to fill job vacancies in different sectors within local Chinese communities and beyond. For instance, many Europe-based small Chinese businesses, such as the tailoring and leather-goods manufacturers in Italy and France, employ almost entirely Chinese staff. Increasing business, which often means greater imports of materials from China, also means increasing staff levels and in turn greater demand for immigrants (Ma, 2011).

Rising consumer power and inequalities in China. The increasing importance of China in the world economy results from not only the rapid growth of its capital and commodity outflows, but also the purchasing power of Chinese citizens abroad, leading to the increasing demand for products and services in or from the EU. A good example reflecting this demand is the increasing popularity of outbound tourism (Arlt 2006; CASS, 2011; CTA, 2011; Latham, 2011a) with more and more Chinese tourists visiting Europe in recent years. In 2010, trips to Europe, which numbered around 3.1 million, accounted for more than 20 percent of all Chinese outbound tourism (excluding travel to Hong Kong and Macao) (ITB, 2011). Official statistics also foresee an annual growth in outbound tourism of between 15 and 20 percent over the next few years (CTA 2011). This tourism is strongly associated with the consumption of luxury goods (Moore, 2011) and also with investment migration and property purchasing in European cities such as London, Paris and Milan.

Although the vast majority of Chinese citizens have gained in some way from China's rise, the distribution of the benefits of its economic development have been quite uneven, with economic and social inequality increasing between different social groups. For instance, rural incomes continue to rise at a slower rate than urban incomes, leading to increasing income gaps between urban and rural residents in term of the ratio of annual net income per capita from 2.65 times in 1999 to 3.33 times in 2009 (see NBS 2009). This uneven development has been closely associated with increasing rural-to-urban migration in China (Pieke and Mallee, 1999; Sun, 2007), and it has two important consequences for international migration. Firstly, social inequality and discrimination, for instance against rural-to-urban migrant workers (Pun, 2003; Yan, 2003), is a major factor driving some Chinese people, including both rural and urban residents, to seek economic opportunities in Europe (Christiansen, 2003), even via illegal channels. Secondly, the authors' fieldwork in Europe has found that income inequalities, which reflect social stratification and labour market segregation in China, have also influenced economic and social structures in overseas Chinese communities in Europe, resulting in poor working conditions and forced labour in some European Chinese businesses (Zanin and Wu, 2012; Wu et al, 2010).

The internationalisation of higher education. The number of Chinese students coming to the EU has shown strong growth in the past decade. Chinese student numbers in the EU in 2010 were approximately six times those in 2000 (GHK, 2011: 18). It is difficult to give precise figures for student numbers but national statistics compiled by the European Commission and the Chinese Ministry of Education suggest that there were around 120,000 Chinese students in the EU in 2011 (GHK, 2011: 18). However, this figure should be taken as indicative rather than as a precise representation of student numbers, and more generous estimates would put it nearer $200,000 .^{5}$ These students come almost entirely from China's growing middle classes, who now find themselves

\footnotetext{
${ }^{5}$ There is much variation between definitions used to identify and count students across different EU countries, and in some cases there is a considerable lack of clarity as to how national statistics have been compiled. For a detailed discussion of the methodological difficulties associated with counting Chinese student numbers in the EU, see GHK, 2011: 19-22).
} 
with sufficient disposable income to send their children overseas to study. Many Chinese students return to China on completion of their studies but employment opportunities in the EU entice many to stay on. Consequently, the trend towards increasing numbers of Chinese students in the EU is also contributing to larger numbers of highly educated and white-collar immigrants. ${ }^{6}$

\section{New features and changes within Chinese communities}

Recent developments in Chinese international migration since the late 1990s have had a profound impact on local Chinese communities in the EU in a number of ways, bringing both new opportunities and new challenges relating to community development and integration. This section highlights some of the key changes that have occurred within Chinese communities in recent years and considers the implications for issues of integration. Further challenging issues will be dealt with in the next section.

\section{The transformation of the Chinese ethnic economy}

The most salient impact of the new cohort of Chinese immigrants is perhaps an ongoing or accelerating process of the transformation of Chinese ethnic economies in terms of industrial structure or ownership since the late 1990s. The former refers to the diversification of Chinese ethnic economic activities, leading to a significant growth of new business sectors such as retailers, tourism and student services in host countries. The latter is related to the emergence of new Chinese entrepreneurs as so many new immigrants have arrived in Europe who have different profiles from the old cohort of Chinese entrepreneurs in terms of the region of origin, educational level, professional background, and principles or visions of business operation.

Bearing in mind the great variation in Chinese businesses across EU member countries, it is impossible to generalise about the transformation of Chinese economies. Instead, drawing upon secondary data and our own observations in Italy and the UK we would like to illustrate some recent developments in Chinese businesses in these countries.

Taking Milan, for example, until recently Chinese there were employed predominantly in shops selling Chinese goods, in catering, import-export companies and wholesale; some were also in fashion manufacturing and selling. Furthermore, in recent years some Chinese have even come to corner markets for some non-Chinese ethnic cuisines, running bars selling Latin American food to Latin American immigrants for instance (Cologna 2011). Chinese now run wedding shops, newspaper stands, barber's shops, tailors, grocery stores and much more. Indeed, in 2012 the number of Chinese businesses offering personal services such as hairdressing, nail treatments or massage increased by 38.8 percent compared with 2011 to more than 2,500 businesses (Europe China News 2013). Many of these businesses are serving the general Milanese community, including Italians and immigrants of all kinds. In fact, there are indications that many Chinese, even first-generation immigrants, are changing their attitude to learning languages. Many are now learning basic conversational Italian, Arabic and Spanish because it is good for business (Cologna, 2011).

\footnotetext{
${ }^{6}$ According to the Chinese Ministry of Education, of the 1,067,000 students who came to the EU to study between 1978 and 2006, only 275,000 returned to China (GHK, 2011:40). However, the trend in recent years has been for a larger proportion of students to return home on completing their studies. The China Scholarship Council reported in 2009 that more than 50 per cent of Chinese students studying overseas did return to China (China Scholarship Council 2009). But even though a higher proportion of students may be returning to China, the growing number of overseas students means that there are still large numbers who remain in the EU.
} 
This kind of diversification is also happening elsewhere in Europe. In London, for instance, the past five years have seen a plethora of Chinese traditional medicine shops opening across the city. Many Chinese have opened nail parlours and it is becoming usual to find Chinese hairdressers and shops selling Chinese goods. This constitutes a significant diversification of Chinese business in the UK, which was for decades heavily concentrated in the catering industry.

The transformation of Chinese economies in the $\mathrm{EU}$ is not limited to the diversification of businesses alone but also relates to the changing Chinese entrepreneurial landscape in terms of place of origin. Taking the East Midlands of the UK as an example, our observations conducted in 2009, indicated that of a total of 61 Chinese businesses, including Chinese restaurants or take-aways, Chinese retailers and herbal medicine shops, over half (52.4\%) were controlled by established Chinese groups including Hong Kongers and other overseas Chinese from Malaysia and Vietnam, 30\% were owned by Southern Chinese, mainly from Fujian and Guangdong, and the remaining one quarter were Dongbeinese or other Northern Chinese (e.g. Shandong, Inner Mongolia, Jilin). The Fujian, Guangdong and Dongbeiness groups between them owned or controlled nearly half of Chinese businesses in the area, which, just a decade earlier were totally owned by Hong Kong and other established Chinese diasporic groups.

\section{Mobility and transnationality of Chinese entrepreneurs}

Another distinctive characteristic related to the new wave of Chinese immigrants to the EU is their mobility and transnationality. Many Chinese stay in a place only for a few years before moving somewhere else, possibly in the same countries but also often elsewhere in Europe. This mobility is especially visible within the Schengen treaty zone, where travelling between the countries with the largest Chinese populations, such as those in Italy, France, Spain and Germany, without a visa is possible. ${ }^{7}$

The transnationality of Chinese immigrants in Europe - the way that they live lives that are regularly informed or shaped by relationships, connections and social practices that cross or defy national boundaries $^{8}$ - can be partly understood in terms of this kind of mobility. The fact that many immigrants do not feel limited by national boundaries but extend their vision to other EU countries when making choices about their life and future in relation to work, education, business or family is an indication of how their lives are transnational. And many Chinese immigrants lead lives that are transnational in other senses. Especially noteworthy are their relationships with China, often conducted through media of one form or another (see below) and the way in which Europe is for many just one possible destination among several. Indeed, in recent years, with the downturn in the European economy, destinations such as Africa and South America have started to look more appealing to many immigrants or would-be immigrants with a keen eye for emerging business opportunities (Polyzou 2011).

\footnotetext{
'In the past, countries such as Spain and Italy have organised amnesties for illegal immigrants (see above), offering them the chance to legalise and document their presence in the country. Such moves have led to surges of immigrants moving from elsewhere in Europe in order to take advantage of these opportunities. However, these surges do not account for the more mundane flow of Chinese immigrants between European countries.

${ }^{8}$ This is broadly in line with Laurence Ma's approach (2005: 4-7) to transnationalism where following Schiller et al. (1992: 1-2) he takes transnationalism as 'the process by which migrants build social fields that link together their country of origin and their country of settlement.' Ma notes that this 'puts heavy emphasis on the process of creating transmigrants' "social fields" and sees transnationalism as a dynamic social process' (Ma 2011: 5).
} 
The diverse opportunities available to Chinese overseas are related at least in part to China's increasingly visible and active presence on the global stage. For example, Chinese government organisations and Chinese businesses investing in Africa, South America and Southeast Asia contribute to building up Chinese ethnic business networks in those countries. And Chinese outward direct investment, which, as we have seen, has been rising sharply in recent years, creates opportunities and markets for Chinese workers and entrepreneurs (Ma 2011).

\section{The emergence and influence of new media}

New media, predominantly the Internet and mobile phones and including new kinds of digital social media, has been increasingly popular amongst Chinese immigrants in the last decade. ${ }^{9}$ With a great potential to influence the degree of integration of Chinese communities in Europe, they have been recognised as an important factor in diasporic identity construction and daily life among overseas Chinese (see, e.g., Sun, 2002; 2007). Chinese in Europe have for years been watching satellite and cable relays of China Central Television's (CCTV) overseas channels while reading a range of Chineselanguage newspapers in Europe, where there are more than a hundred Chinese-language newspaper and magazine publishers (Zhou 2011). Chinese-language newspapers have long played a central role in providing Chinese communities with news about Chinese community leaders in Europe and also important classified advertisements for those seeking work or to buy or sell businesses or other property.

However, an ever more important feature of overseas Chinese communities is their now extensive reliance upon new media. New media are accompanying a transformation of the way of life of overseas Chinese communities in Europe. They open up new links to China as well as to other Chinese in Europe or other parts of the world and also offer new opportunities for business, communication, entertainment and information-gathering. Although new media have been widely available for more than a decade, there has been a major expansion of new media use in recent years. In particular, online video and broadcasting have opened up new modes of mass media consumption, e.g.online television, radio and newspapers, while social media have created new possibilities for Chinese immigrants to link up with each other for social, business or leisure purposes.

In many parts of Europe, Chinese immigrants are now watching local television stations from China, e.g. Zhejiang Television or Wenzhou Television, over the Internet. They also often access Chinese newspapers and general Chinese web portals such as Sina.com, Sohu.com or QQ.com. The Internet is also used widely for instant messaging with other Chinese both in Europe and back in China, with QQ probably the most popular service. Some Chinese also read and write blogs and micro-blogs while many participate in online bulletin board system discussions. The Internet is also used widely for gathering news and information of all kinds and, perhaps most of all, as a medium for entertainment, such as online gaming, watching online television and film and downloading music.

In recent years, new media have played a big part in forming notions of identity among secondgeneration European Chinese. In the UK, websites such as www.dimsum.co.ukor www.britishchineseonline.com have created new spaces for reflection, dialogue and debate, information-sharing and expressions of emotional support (Song, 2011).Similar websites in other European countries have played a corresponding role. In countries such as the UK and the Netherlands, where the principal economic activity of overseas Chinese has been in the catering sector, a strong sense of community among Chinese was often lacking before the possibilities that

\footnotetext{
${ }^{9}$ By 'new media' we refer principally to the Internet and mobile telephony although other digital media, such as DVDs, satellite television, online video and broadcasting and digital photography, are important too.
} 
new media offer. Chinese families, often running the one Chinese restaurant or take-away in a small town or village, had very little contact with other Chinese people. New media can thus be associated in some cases with the formation of a sense of second-generation Chinese diasporic identity (Parker and Song, 2006).

With the growing significance of new media in various aspects of identity-formation among Chinese immigrants in Europe, it is clear that new media have the potential both to link immigrants more strongly to their home communities and to detach them further from the immediate contexts of their host countries (Denison and Johanson, 2009; Johanson and Fladrich, 2011). However, Chinese immigrant media can also work to encourage better integration and affiliation with host communities (Zhou, Chen and Cai, 2006; Zhao 2006).

\section{New challenges facing Chinese communities}

A range of complex factors including language and different cultural traditions have meant that the processes of integration of Chinese international migrants and overseas Chinese communities worldwide has been varied and uneven (Wang and Liu, 2011). Thinking of integration as a process of effective communication, interaction and cooperation of all Chinese groups with their counterparts in mainstream societies, this section aims to highlight a number of challenging issues facing Chinese communities: changes to immigration policies in many EU countries and social isolation and poor working conditions of Chinese migrant workers in some Chinese-owned workplaces.

\section{Impact of immigration policies}

Given the increasing demand for Chinese migrant workers in host countries across the EU, it may be useful to consider a specific example. Table 2 illustrates the development of Chinese businesses registered in Veneto since the 1970s and strong demands for Chinese labour in Chinese-owned workplaces including Chinese catering, manufacturing, trade and retail shops up until the early 2000s. The rapid growth in the number of Chinese businesses led to a shortage in Chinese labour in many of them. Despite many amnesties in Italy and other countries (Denison et al., 2009; Soothill, 2010), according to our observation (Zanin and Wu,2012), irregular migrant workers accounted for up to $20 \%$ of the total of Chinese workers in those factories sampled for that research.

Table 2: Chinese Entrepreneurs registered in the Trade Chambers in Veneto, 1970-2005

\begin{tabular}{|l|c|c|c|c|}
\hline Sector & $1970-79$ & $1980-89$ & $1990-99$ & $2000-05$ \\
\hline Bar/cafe/restaurant & 6 & 30 & 132 & 609 \\
\hline Trade/retail & 0 & 3 & 61 & 934 \\
\hline Factories & 0 & 1 & 104 & 1,299 \\
\hline Other activities & 0 & 1 & 15 & 61 \\
\hline Total & 6 & 35 & 312 & 2,903 \\
\hline
\end{tabular}

Source: Elaboration by Valter Zanin based on data of InfoCamere, Unioncamere, Veneto, Italy (see Zanin 2012).

A similar story can be told relating to the growth of Chinese catering outlets in the UK from 15,000 in 2001 to 17,500 in 2008. One recent estimate suggested that this new growth in labour demand led to a shortfall of more than 60,000 Chinese workers out of a potential 100,000 job opportunities (Lam 2009). As a result, the shortage of Chinese migrant workers has become a serious issue facing Chinese businesses and the Chinese community in the UK. 
The gaps between the demand for and the supply of Chinese migrant workers via legal channels in the UK and other EU countries have inevitably led to the establishment and development of international networks for irregular migration from China to Europe (ref). No reliable data is available for irregular Chinese population in the $\mathrm{EU}$ and some of conservative estimation is about $10 \%$ of local Chinese populations $(\mathbf{L i}$,

The dependency upon irregular migrant workers in many Chinese businesses has serious consequences in terms of integration. Firstly, it prevents Chinese businesses and Chinese communities from opening up to their host societies for fear of incurring penalties for the employment of irregular migrant workers. Secondly, it also deters Chinese migrant workers from communicating more fully with their local host communities through fear of the discovery of illegalities in their situation, about the potential loss of work opportunities and even deportation.

The constraints of migration policies have become even more salient in recent years. Owing to the global economic recession, many EU countries have adjusted immigration policies, leading to tougher border controls and efforts to clamp down on illegal immigration. As a case in point, the Italian town of Prato, for decades a fortress of the centre-left Italian parties, has been ruled since 2009 by a centre-right local government elected on the basis of a heavily anti-immigration, and particularly anti-Chinese-immigration, agenda. Since coming to power, the local government has sought to crack-down on illegal businesses, tax evasion, poor working conditions in Chinese workshops and other regulation violations such as rubbish disposal. This has led to tension not only between the two sections of the local population but also between the Chinese embassy and the authorities in Rome. It is too early to assess fully the impact of such hardening attitudes on immigration trends. However, initial indications are that they may deter some immigrants from coming to Prato and encourage others to consider moving, either as individuals or businesses, elsewhere in Italy or Europe. ${ }^{10}$

As immigration has become a more sensitive political issue in some major European countries, e.g. the UK and France (see Kofman, Rogoz and Lévy, 2010), some countries have introduced stricter controls on immigration. After the UK general election in 2010, for instance, the coalition government followed through with a Conservative Party election pledge to introduce a cap on the number of immigrants coming into the country from non-EU countries. The UK authorities have also introduced a range of measures aimed at reducing both regular and irregular non-EU immigration. Among them are tighter rules for Tier 4 visa applications (UKIN, 2011a), limitations on Tier 2 intracompany transfer visas (UKIN, 2011b), the introduction of biometric residence permits for immigrants (UKIN, 2011c) and tightening language test requirements for Tier 1,2 and 4 visa applicants (UKIN, 2011d). ${ }^{11}$

From the integration perspective, a friendly and mutually respective environment could be very helpful for those new Chinese migrant workers to develop their confident and effective communication channels with local counterparts including trade unions and civil society organisations for mutual understanding and support. In this regard, the changes of immigration

\footnotetext{
${ }^{10}$ No systematic statistical data is available yet to confirm this trend. It has only tentatively been identified by the authors of this report through interviews with Chinese immigrants and community representatives during fieldwork in Prato between May and September 2011 and Milan 2013

${ }^{11}$ The UK immigration system is based upon the notion of five tiers with each tier having different conditions, entitlements, and entry requirements for potential immigrants to the country. Tier 1 is for entrepreneurs, investors and graduate students, tier 2 is for skilled workers with a job offer, tier 3 for low-skilled workers meeting temporary labour shortages, tier 4 is for foreign students and tier 5 is for youth mobility and temporary workers (UKBA 2012: 5-6).
} 
policies in many countries may have a negative impact on those vulnerable immigrants who could benefit most from contact and communication with local host communities.

\section{Social isolation of Chinese migrant workers}

The difficulty Chinese migrant workers encounter in integrating into local communities is not only caused by tougher immigration policies in host countries, but is also related to the structure of overseas Chinese communities which are characterised by closure, segmentation and fragmentation (Wu, 2010; Liu, 2013: 231-236;). As a result, Chinese migrant workers are the most vulnerable group in the bottom of Chinese communities, whose voices, needs and sufferings can hardly be heard from the outside.

The nature of the social isolation experienced by Chinese migrant workers, according to our observation in Italy and the UK (Wu and Sheehan 2011, Wu et al 2010), can be measured by paying attention to the following features: whether or not their voices are to be heard by either the outside (local mainstream societies) or inside (Chinese community members); whether their exist channels for them to express their interests and communicate to other groups; whether or not there are external resources and social support available to them. Social isolation among Chinese migrant workers is therefore the most challenging issue facing Chinese communities in host countries.

There are many factors contributing to the social isolation of Chinese migrant workers today. Besides the Chinese community structure, according to our empirical studies, the following factors cannot be ignored.

- Poor language skills which prevent most of them from finding job opportunities with employers other than Chinese;

- Dependency upon Chinese employers or other Chinese community support groups in terms of not only employment opportunities but also other services such as translation, accommodation, dealing with bureaucracy and transportation;

- Short-term vision or thinking focused upon making money to relieve poverty or service heavy loans for their international migration;

- Underdeveloped civil society organisations within Chinese communities capable of properly representing Chinese migrant workers.

Social isolation as a key indicator reflecting the poor status of Chinese integration in the new century has many negative consequences on Chinese migrant workers in both physical and mental health. The former can be seen in the difficulties that migrant workers face in accessing local medical services, for example, leading to them frequenting popular underground Chinese clinics with a range of potential risks involved (Wu and Zanin, 2008). The latter can be seen from many mental health issues amongst Chinese migrant workers (Wu et al 2010).

\section{Poor working conditions and forced labour in some Chinese businesses}

One of the consequences of the social isolation of Chinese migrant workers is the poor working conditions in some Chinese-owned workplaces in Europe where disenfranchised workers have no voice. The poor working conditions in Chinese-owned businesses can be seen from a detailed comparison between Chinese- and Italian-owned factories in the textile, garment and leather sectors (Zanin and $\mathrm{Wu}, 2009$ ). Research suggests that despite a higher income available from the former, many Chinese workers nonetheless preferred to work with Italian employers, where they felt free from the extremely long working hours each day with no welfare and no insurance. 
Another survey, conducted in the East Midlands of the UK by one of the co-authors and sponsored by the International Labour Organization, suggests not only that irregular migrant workers are often abused and exploited in the workplace but also that some legal migrant workers with work permits such as Chinese chefs or doctors of traditional Chinese medicine may also be subjected to conditions of bonded labour and abuse. In such cases, they have their personal identity documents taken away by the labour agents who find them work or by their employers. They then have to pay either a large one-off payment or a large proportion of their monthly salary in the hope of eventually getting their documents back (Wu et al, 2010).

The issues of Chinese sweatshop labour that exist in some Chinese-owned businesses in Europe cannot be blamed merely on the bad behaviour of a few Chinese entrepreneurs. It is a more complex structural issue, related to many complicated factors, especially the characteristics of overseas Chinese communities ( $\mathrm{Wu}, 2010)$. As a result, the voices, needs and sufferings of exploited Chinese migrant workers are rarely heard.

Just as in recent years there have been increasing protests and labour movements in China, so a new class consciousness has emerged among new Chinese migrant workers to Europe, even though they often have only limited influence ( $\mathrm{Wu}$ and Liu, 2013). This trend is evidenced by several developments: violence against bosses in some workplaces and workers joining local trade unions and even creating Chinese trade unions, such as the Chinese migrant network in London.

\section{Conclusions}

This chapter aims to reveal the latest developments, characteristics and new dynamics of Chinese immigration to the EU since the late 1990s, and their impact on local Chinese communities. A number of conclusions can be drawn as fellows.

Firstly, the new wave of Chinese immigrants to the EU, which started from the late 1970s, has experienced accelerating growth in the last decade, leading to an expansion of the Chinese population in almost all EU countries though to varying extents in different countries.

Secondly, recent Chinese immigration has been driven by a number of factors, which include but are not limited to: state-owned enterprise (SOE) reform in China, China-Europe trade growth, rising consumer power and inequality in China, as well as the internationalisation of higher education. These new dynamics, which, one could argue, are unique in the history of Chinese international migration, have had a profound impact on local Chinese communities in the EU in various ways, both quantitatively (increasing demand for migrant labour to support the growth of Chinese ethnic economies) and qualitatively (structural adjustment of Chinese businesses and communities).

Thirdly, the impact on local Chinese communities across the EU can be analysed in relation to three features: 1) the transformation of Chinese ethnic economies in terms of business structure (diversification instead of single and traditional catering or manufacturing only) and profiles of entrepreneurship (pluralism in regions of origin, education and professionalism); 2) high mobility and transnationality across the boundaries of EU countries and between EU and China; 3 ) mushrooming and increasing influences of new Chinese media.

Finally, a number of challenging issues facing Chinese communities have been identified, including: the constraints from immigration policies and changes in recent years; social isolation and in some cases poor working conditions in many Chinese owned businesses. Further research is needed to 
identify the potential, space and new mechanism for local Chinese community development and integration. 


\section{References}

Arlt, Wolfgang (2006), China's Outbound Tourism, London: Routledge.

Atsmon, Yuval, Dixit, Vinay, Magni, Max and St Maurice, Ian (2010),'China's New Pragmatic Consumers', McKinsey Quarterly, October 2010; last viewed at

http://www.mckinseyquarterly.com/Marketing/Sales_Distribution/Chinas_new_pragmatic_consumers_2683?gp=1, 08/09/2011.

BCC(2010), The Keys to the Kingdom: Unlocking China's Consumer Power, Boston: Boston Consulting Group.

Benton, Gregor and Gomez, Edmund T. (2008), The Chinese in Britain, 1800-present: economy, transnationalism, identity, Basingstoke: Palgrave Macmillan

Benton, Gregor and Pieke, Frank N. (1998)(eds), The Chinese in Europe, Basingstoke: Palgrave Macmillan.

Blanchard, Melissa and Maffeo, Carlotta (2011), 'L'immigrazionecinese in Italia e Torino', in Camera di CommerciolndustriaArtigianato e Agricoltura di Torino, DiventareLaoban: Lavoroautonomo, percorsiimprenditoriali e progettimigratorideicinesi in Italia e Torino, Turin, Italy: Camera di CommerciolndustriaArtigianato e Agricoltura di Torino.

Bowlby, Chris (2011), 'Do Denmark's immigration laws breach human rights?'; last viewed on 14 March 2012 online at http://www.bbc.co.uk/news/world-europe-12366676.

Branigan, Tania (2012), 'China's Economic Growth slows to 7.6\%.' The Guardian online at: http://www.guardian.co.uk/business/2012/jul/13/china-economic-growth-slows-gdp, last accessed 25/2/13.

Chan, Kwok-Bun (2005), Chinese Identities, Ethnicity and Cosmopolitanism, London and New York: Routledge.

Chinese Academy of Social Sciences (CASS)(2011).2011 年中国旅游发展分析与预测(China's Tourism Development Analysis and Forecast (2011).Chinese Academy of Social Sciences Tourism Research Centre Green Book on Chinese Tourism. Beijing: Social Sciences Academic Press (in Chinese ).

China Tourism Academy (CTA)( 2011), CTA Annual Report of China Oubound Tourism Development 2011. Beijing: Tourism Education Press.

Castagnone, Eleanora and Blanchard, Melissa (2011), 'Chinese entrepreneurship in Turin: Individual trajectories, networks, regulatory framework and the role of the local context.' Paper presented to the 4th Chinese in Prato and 2nd Wenzhounese Diaspora Symposia, Prato, Italy, 20 September 2011.

Ceccagno, A. (2009), 'La diaspora cinese', in Samarani, G and Scarpari, M, La Cina III: Verso la modernita, Turin, Italy: Einaudi.

Ceccagno, A. and Rastrelli, R. (2008), Ombre cinesi? Dinamiche migratory della diaspora cinese in Italia, Rome: Carocci. 
Chen, Anjin(2011), 'An Analysis on the Migration Route, Occupation Changes and Social Integration of China's Overseas Immigrants: A Case Study of Wenzhou', paper presented to the4th Chinese in Prato and 2nd Wenzhouese Diaspora Symposia, 20-21 September, Monash University, Prato Centre, Prato, Italy.

China Daily (2011), 'China backs Europe amid debt crisis', online at www.chinadaily.com; last accessed10 October 2011.

China Labour Information Network (CLIN)(1999), Research report on the reemployment training programme for former SOE workers who have been redundancy (in Chinese), online at http://www.51labour.com/labour-law/show-4948.html.

Christiansen, Flemming (2003),Chinatown Europe: an exploration of overseas Chinese identity in the 1990s, London: RoutledgeCurzon.

Cologna, Daniele (2011), 'Getting closer: Shifting identities, socio-economic roles and perceptions of the other in the Chinese-Italian experience.' Paper presented to the China in the World Conference, 22-23 September, Monash University, Prato Centre, Prato, Italy.

Denison, Tom; Arunachalam, Dharmalingam; Johanson, Graeme and Smyth, Russell (2009), 'The Chinese Community in Prato', in Graeme Johanson, Russell Smyth and Rebecca French (eds), Living Outside the Walls: The Chinese in Prato, Newcastle-upon-Tyne: Cambridge Scholars Publishing, pp. 224.

Denison, Tom and Johanson, Graeme (2009), 'Community Connections: The Chinese Community in Prato, Italy, and their use of Technology', in Graeme Johanson, Russell Smyth and Rebecca French (eds), Living Outside the Walls: The Chinese in Prato, Newcastle-upon-Tyne: Cambridge Scholars Publishing, pp.161-173.

De Pretto, Laura (2011), “"Who am I?" Identity construction processes in Wenzhounese moving to Italy', paper presented to the 4th Chinese in Prato and 2nd Wenzhounese Diaspora Symposia, Prato, Italy, 20 September.

Dinmore, Guy (2011), 'Italy Turns to China for Help in Debt Crisis.' The Financial Times, online at: http://www.ft.com/cms/s/0/90c4c7f6-dd54-11e0-9dac-00144feabdc0.html\#axzz2LxDYCSvT, last accessed 25/2/13.

Europe China News 2013. ‘在意华人经营的个人服务企业年增 38.8\%” 欧洲侨报， $27 / 08 / 13$, page 4.

European Migration Network (EMN)(2011), European Migration Network statistics databases; available online at http://emn.intrasoft-intl.com/html/index.html.

Eurostat (2011), European Commission statistics databases; available online at http://epp.eurostat.ec.europa.eu/portal/page/portal/eurostat/home.

GHK (2011), EUChina Student and Academic Staff Mobility: Present Situation and Future Developments, a joint study between the European Commission and the Ministry of Education in China, Brussels: GHK Consulting and Renmin University; last viewed online on 14 March 2012 at http://ec.europa.eu/education/external-relation-programmes/doc/china/mobility en.pdf. 
Gao, Yun (2010), Concealed Chains: Labour exploitation of Chinese migrants in Europe, Geneva : International Labour Organisation

Gui,Shixu (2011), 'The contribution of overseas Chinese to China's development', in Qu, Zhang, Luo and Li (eds), Annual Report on Overseas Chinese Studies (2011), Beijing: Social Sciences Academic Press (in Chinese), pp. 51-84.

Gulyas, Veronika and Fletcher, Owen (2011), 'China Pledges Continued Support for European Debt', Wall Street Journal, online at http://www.wsj.com; last accessed on 10 October 2011.

ITB 2011.ITB World Travel Trends Report 2010/2011.Prepared by IPK International on behalf of ITB Berlin. Munich: IPK International.

Johanson, Graeme and Fladrich, Anja Michaela (2011), 'Ties that bind: Information and communications technologies and the Chinese in Prato.' Paper presented to the 4th Chinese in Prato and 2nd Wenzhounese Diaspora Symposia, Prato, Italy, 20 September 2011.

Kofman, Eleonore; Rogoz, Madalina and Lévy, Florence (2010),Family Migration Policies in France, International Centre for Migration Policy Development, available online at http://ec.europa.eu/ewsi/UDRW/images/items/docl 14977 276188113.pdf.

Lam, Jabez (2009), 'Labour shortage in Chinese Catering', a presentation to The University of Nottingham-International Labour Organisation Workshop: Impployment of Chinese Migrant Workers in UK: Issues and Solutions, 22-23 October 2009, Nottingham. Online at:

http://www.nottingham.ac.uk/cpi/documents/funded-projects/ilo-workshop-complete-report.pdf

Latham, Kevin (2011a),How the rise of Chinese tourism will change the face of the European travel industry, SOAS-Hilton Blue Paper, London: SOAS-Hilton Hotels.

Latham, Kevin (2011b), 'Media and discourses of identity in Prato, Italy.' Paper presented to the4th Chinese in Prato and 2nd Wenzhouese Diaspora Symposia, 20-21 September, Monash University, Prato Centre, Prato, Italy.

Li, Minghuan (2011a), 'Latest development and trends of overseas Chinese in Europe', in Wang and Liu (eds), Overseas Chinese and Local Society in Europe: Social Integration, Economic Development and Political Participation,Guangzhou: Zhongshan University Press (in Chinese), pp. 3-25.

Li Minghuan (2011b), 'The Chinese in Europe: Population, economy and links with China in the early 21st Century', paper presented to the China in the World Conference, 22-23 September 2011, Monash University, Prato Centre, Prato, Italy.

Li, Peilin and Roulleau-Berger, Laurence (eds) 2012. China's Internal and International Migration. London: Routledge.

Ma, Laurence J.C. 2003. 'Space, Place and Transnationalism in the Chinese Diaspora.' In L. J.C. Ma and C. Cartier (eds.) The Chinese Diaspora: Space, Place, Mobility and Identity. New York: Rowman and Littlefield.

Ma, MungKuang(2011), 'Economic and social integration of migrants of Chinese origin in France', 
paper presented to the China in the World Conference, 22-23 September 2011, Monash University, Prato Centre, Prato, Italy.

Moore, Malcolm (2011), 'Chinese tourists bring $£ 200 m$ windfall for London retailers', Daily Telegraph, 24 May; available online at http://www.telegraph.co.uk/finance/chinabusiness/8534189/Chinese-tourists-bring-200m-windfall-for-London-retailers.html, last accessed on 8 September 2011.

Nyiri, Pal (2003), 'Chinese Migration to Eastern Europe.' International Migration Vol. 41(3): 239-265.

Parker, David and Song, Miri (2006), 'New ethnicities online: reflexive racialisation and the internet.' The Sociological Review, 54(3): 575-94.

Pai, Hsiao-Hung (2008), Chinese Whispers: The True Story Behind Britain's Hidden Army of Labour, London: Penguin Books.

Pastore, Ferruccio and Castagnone, Eleonora(2011), 'Studiarel'imprenditoriacinese, oltreiluoghicomuni', in Camera di CommerciolndustriaArtigianato e Agricoltura di Torino, Diventare Laoban: Lavoroautonomo, percorsiimprenditoriali e progettimigratorideicinesi in Italia e Torino, Turin, Italy: Camera di CommerciolndustriaArtigianato e Agricoltura di Torino.

Pieke, Frank (2004), 'Chinese Globalization and Migration to Europe', Working Paper No. 94, the Centre for Comparative Immigration Studies, University of California, San Diego, March 2004.

Pieke, Frank N. (1998), 'Introduction', in Benton and Pieke (eds), The Chinese in Europe, London and New York: Macmillan, pp. 1-17.

Pieke, Frank N. and Mallee, Hein (eds) (1999), Internal and International Migration: Chinese Perspectives, Richmond: Curzon Press.

Pieke, Frank N.; Nyir, Pal; Thuno, Mette; and Ceccagno, Antonetlla (2004), Transnational Chinese: Fujianese Migrants in Europe, Stanford: Stanford University Press.

Pieraccini, Silvia (2008), L'AssedioCinese: Ildistrettoparallelo del pronto moda a Prato, Milano: Edzioni II Sole 24 Ore.

Polyzou, Iris (2011), 'Chinese migration in Athens: Socio-spatial practices, new challenges and perspectives during the economic crisis', paper presented to the 4th Chinese in Prato and 2nd Wenzhouese Diaspora Symposia, 20-21 September 2011, Monash University, Prato Centre, Prato, Italy.

Polyzou (2011). Personal communication.

Qu, Jin, Zhang, Yudong, Luo, Kereng and Li, Minghuan (eds) (2011), Annual Report on Overseas Chinese Studies(2011), Beijing: Social Sciences Academic Press (in Chinese).

Reuters (2011), 'China's Huawei picks Hungary for logistics centre', http://www.reuters.com. 
Sandford, Daniel (2010), 'Illegal immigration: is an amnesty the answer?' last viewed on 14 March 2012at

http://news.bbc.co.uk/2/hi/uk news/politics/election 2010/parties and issues/8629354.stm.

Shen, Wei (2009), Chinese Student Circular Migration and Global City Formation: A relational case study of Shanghai and Paris, unpublished PhD thesis, Loughborough University.

Schiller, Nina, Glick, Linda Basch and Blane, Christina (eds.) 1992. Towards a Transnational Perspective on Migration: Race, Class, Ethnicity and Nationalism reconsidered. New York: New York Academy of Sciences.

Song, Miri (2011), 'Is the British Chinese case a typical trajectory of "integration"?' Paper presented to the China in the World Conference, 22-23 September 2011, Monash University, Prato Centre, Prato, Italy.

Soothill, Deborah (2010), Eating bitterness: An ethnographic study of the Chinese migrant experience in Madrid, unpublished PhD thesis, Department of Anthropology, University College London.

Sun, Wanning (2002), Leaving China : media, migration, and transnational imagination, Lanham: Rowman \& Littlefield.

Sun, Wanning (2007), Maid in China: Media, mobility and a new semiotic of power, London: Routledge.

Sun, Wanning (ed.) (2006), Media and the Chinese Diaspora: Community, Communications and Commerce, London: Routledge.

Tomba, Luigi (2004), 'Creating an Urban Middle Class: Social Engineering in Beijing.' The China Journal, No. 51: 1-26.

UKBA 2012. 'Skilled Shortage Sensible: Call for Evidence: Review of the shortage occupation lists for the UK and Scotland and Creative Occupations.' London: UKBA. Online at:

http://www.ukba.homeoffice.gov.uk/sitecontent/documents/aboutus/workingwithus/mac/ukscotland-creative-occ.pdf. Last accessed 25/2/13.

UKIN (UK Immigration News) (2011a), 'UK universities war of negative effects of tighter tier 4 student visa rules'; last viewed online on 14 March 2012 at http://www.ukimmigration.com/news/2012-03-05/uk/uk-universities-warn-of-negative-effects-oftighter-tier-4-student-visa-rules.htm.

UKIN (2011b), 'UK immigration could clamp down on tier 2 intra-company transfer visas'; last viewed online on 14 March 2012at http://www.ukimmigration.com/news/2012-03-02/uk/uk-immigrationcould-clamp-down-on-tier-2-intra-company-transfer-visas.htm.

UKIN (2011c), 'UK immigration to expand biometric residence permits for immigrants'; last viewed onlineon 14 March 2012at http://www.ukimmigration.com/news/2012-03-02/uk/uk-immigrationto-expand-biometric-residence-permits-for-immigrants.htm.

UKIN (2011d), 'Changes to UK immigration English test for tier 1, 2 and 4 applicants'; last viewed online 14 March 2012at http://www.ukimmigration.com/news/2012-02-02/uk/changes-to-ukimmigration-english-test-for-tier-1-2-and-4-applicants.htm. 
Wang, Wangbo and Zhuang, Guotu (2010)), Review of Overseas Chinese 2008,Beijing: World Knowledge Press (in Chinese).

\section{Wang, Xiaoping and Liu, Hong (2011), European Diaspora Chinese in Local Communities: Social interaction, economic development and political participation, Guangzhou: Zhongshan Univcersity Press (in Chinese)}

Wu, Bin (2008), 'Vulnerability of Chinese Migrant Workers in Italy: Empirical Evidence of their Working Conditions and the Consequences', China Policy Institute Discussion Paper Series, Issue 28; online at http://www.nottingham.ac.uk/cpi/publications/discussion-papers/2008/index.aspx.

Wu, Bin (2010), 'Overseas Chinese Community Building (CCB): Approach and Practice', China Policy Institute Policy Paper Series,Issue 65; online at

http://www.nottingham.ac.uk/cpi/publications/policy-papers/2010/index.aspx.

Wu, Bin, Guo, L. and Sheehan, J. (2010),Employment Conditions of Chinese Migrant Workers in the East Midlands: A pilot study in a context of economic recession, a report submitted to the ILO, Beijing: International Labour Office for China and Mongolia.

Wu, Bin and Liu, Hong (2013), 'Bring class back in: Class consciousness and solidarity amongst Chinese migrant workers in Italy and the UK', Ethnic and Racial Studies, forthcoming. Online available at: http://www.tandfonline.com/doi/abs/10.1080/01419870.2012.715660

Wu, Bin and Sheen, Jackie (2012), 'Globalization and vulnerability of Chinese migrant workers in Italy: Empirical evidence on working conditions and their consequences', Journal of Contemporary China 20, 68: 135-152.

Yan, Hairong(2003), 'Spectralization of the Rural: Reinterpreting the labor mobility of rural young women in post-Mao China.'American Ethnologist 30(4):578-96.

Yao, Yuan (2011), 'Italian overseas Chinese who integrate into mainstream society should not throw away their Chinese culture' [Yidalihuaqiaoruzhuliushehuibuyingfangqizhoanghuawenhua];accessed online at www.ouhuaitaly.com andlast viewed 19/September 2011.

Yeung, Yue-man 2002. Internal and International Migration in China under Openness and a Market Economy. Hong Kong: Hong Kong Institute of Asia-Pacific Studies with Chinese University of Hong Kong Press.

Zanin, Valter (2012), Immigrati cinesi operai e imprenditori nella terra di Marco Polo, vol. $1^{\circ}$, L'organizzazione del lavoro in Italia e nel Veneto alla luce delle migrazioni cinesi [Chinese migrants workers and entrepreneurs in the land of Marco Polo, vol. $1^{\circ}$, The organization of work in Italy and Veneto in the light of the Chinese migrations], Padova, Cleup, ISBN: 978-88-6129-988-7.

Zanin, Valter and Wu, Bin (2012), Immigrati cinesi operai e imprenditori nella terra di Marco Polo, vol. $\mathrm{II}^{\circ}$, Condizioni di lavoro e salute degli operai cinesi tra Zhejiang e Italia (Veneto) [Chinese migrants workers and entrepreneurs in the land of Marco Polo, vol. $11^{\circ}$, Working and Health Conditions of the Chinese workers between Zhejiang and Italy (Veneto)], Padova, Cleup, ISBN: 97888-6129-990-0. 
Zhang, Li (2008), 'Private Homes, Distinct Lifestyles: Performing a New Middle Class', in Li Zhang and AihwaOng (eds),Privatizing China: Socialism from Afar, Ithaca/London: Cornell University Press.

Zhao, Xiaojian (2006), 'Disconnecting transnational ties: the Chinese Pacific Weekly and the transformation of Chinese American community after the Second World War.' In Sun Wanning (ed.) Media and the Chinese Diaspora: community, communications and commerce. New York: Routledge, pp.26-41.

Zhou, Yongming 2011. 'Social Capital in Print: Chinese newspaper publishing in Italy.' Paper presented to the China in the World Conference, 22-23 September 2011, Monash University, Prato Centre, Prato, Italy.

Zhou, Min; Chen, Wenhong and Cai, Guoxuan(2006), 'Chinese-language media and immigrant life in the United States and Canada', in Sun Wanning (ed.), Media and the Chinese Diaspora: community, communications and commerce, New York: Routledge, pp.44-74.

\footnotetext{
'The following sources were used, where available: European Union and European Commission reports and statistical datasets publicly available online or in published documents. The compilation of statistical data may be problematic, due to following reasons: the variety of definitions and methodologies adopted by different sources of statistical data; inconsistent across different data sources; comparability of different data sources.
} 